\section{Buffered Ethanol Fixative}

DOI: $10.1369 / 0022155416687278$

\section{John A. Kiernan}

Department of Anatomy and Cell Biology, University of Western

Ontario, London, Ontario, Canada (JAK)

\section{Keywords}

alcohol, fixation, molecular pathology

In the recent Journal of Histochemistry \& Cytochemistry (JHC) article by Perry et al., ${ }^{1}$ a fixative mixture designated "buffered ethanol 70\%" (BE70) was judged best for preserving structural integrity, providing satisfactory immunostaining with three commonly used antibodies, and for allowing optimal extraction and amplification of nucleic acids. In the abstract, BE70 is called "phosphate buffered ethanol $70 \%$." The designation "buffered ethanol $70 \%$ (BE70)" is used also in the legends of Figures 1, 2, and 3. In the "Methods" section of the article, " $70 \%$ ethanol $+0.5 \times$ phosphate-buffered saline ... (EP)" most accurately corresponds to "phosphate buffered ethanol $70 \%$," but BE70 is identified as " $70 \%$ etha$\mathrm{nol}+1 \%$ glycerol $+0.5 \%$ glacial acetic acid $+0.5 \times$ PBS (EGAP; BE70)." The article does not provide enough information to allow other investigators to make the mixture that the authors favored for combined histological and biochemical preservation. If BE70 is a mixture in which acetic acid and a phosphate-buffered aqueous salt solution were mixed with ethanol, what is its approximate $\mathrm{pH}$ ? This information is needed to define the composition of the BE70 fixative.

\section{Literature Cited}

1. Perry C, Chung JY, Ylaya K, Choi CH, Simpson A, Matsumoto KT, Smith WA, Hewitt SM. A buffered alcohol-based fixative for histomorphologic and molecular applications. J Histochem Cytochem. 2016;64:425-40.

Received for publication November 3, 2016; accepted December 7, 2016.

\section{Corresponding Author:}

John A. Kiernan, Department of Anatomy and Cell Biology, University of Western Ontario, London, Ontario, Canada N6A 5CI.

E-mail: jkiernan@uwo.ca

\section{Formulation and $\mathrm{pH}$ of the Buffered Ethanol Fixative BE70}

DOI: $10.1369 / 0022155416687279$

\section{Stephen M. Hewitt}

National Cancer Institute, National Institutes of Health, Bethesda, Maryland (SMH)

\section{Keywords}

alcohol, fixation, formalin, histomorphology, paraffin embedded, real-time RT-PCR, RNA integrity, tissue

In response to the letter to the editor by Kiernan ${ }^{1}$ concerning details on formulation and $\mathrm{pH}$ of $\mathrm{BE} 70,{ }^{2}$ we apologize for the inconsistent use of abbreviations in the formulation of the fixative. Our initial discovery was that a fixative of $70 \%$ ethanol made with (1x) PBS was superior to a fixative of $70 \%$ ethanol made with distilled water. This initiated a series of studies, of which only a limited number of combinations could be accommodated in the final article, resulting in the final fixative we termed BE70.

The notation "(EGAP; BE70)" would have been better left as only "BE70." "EGAP" is the internal laboratory shorthand of the components-ethanol, glycerol, (glacial acetic) acid, and $\mathrm{P}(\mathrm{BS})$. The formulation of BE70 is as stated:

$70 \%$ ethanol, absolute

$1 \%$ glycerol

$0.5 \%$ glacial acetic acid

$28.5 \% 0.5 \times$ PBS.

This rather arcane approach to describing the formulation of solutions is in fact common to many

Received for publication December 6, 2016; accepted December 7 , 2016.

\section{Corresponding Author:}

Stephen M. Hewitt, Experimental Pathology Laboratory, Laboratory of Pathology Center for Cancer Research, National Cancer Institute, National Institutes of Health, 10 Center Drive, Bethesda, MD 20892, USA. E-mail: genejock@helix.nih.gov 
histology manuals. A more standard recipe for BE70 is as follows.

First prepare stock solution consisting of $50 \mathrm{ml}$ of $10 \times$ PBS (pH 7.4), $12.5 \mathrm{ml}$ of $80 \%$ glycerol, and $5 \mathrm{ml}$ of glacial acetic acid. Adjust the $\mathrm{pH}$ to 4.3 with $\mathrm{NaOH}$ and then fill to $300 \mathrm{ml}$ with distilled water. Before use, mix $300 \mathrm{ml}$ of this stock solution and $700 \mathrm{ml}$ of absolute (200 proof) EtOH for a total volume of $1000 \mathrm{ml}$. The $\mathrm{pH}$ of the final composition is approximately 6.1 , and the fixative has no precipitate at $4 \mathrm{C}$ storage.

In reference to the $\mathrm{pH}$ of $\mathrm{BE} 70$, we evaluated BE70 at different $\mathrm{pH}$ values ranging from 4 to 7 , and were unable to discern a measurable difference in histomorphology or RNA quality, which we have previously demonstrated to be the most sensitive metric for tissue fixation and processing ${ }^{3}$; however, we chose a more neutral $\mathrm{pH}$ in an effort to avoid requiring additional shipping and storage precautions associated with acid $\mathrm{pH}$ reagents, as well as not damage tissue processing hardware. The subject of fixative $\mathrm{pH}$ is complex. To our knowledge, the first report concerning the introduction of buffers into a fixative is from 1894 by Mann, ${ }^{4}$ as recounted by Burke, ${ }^{5}$ who argued for pyridine-formalin. Lillie comments on the common use of calcium carbonate and magnesium carbonate as buffering agents, resulting in $\mathrm{pH}$ levels between 6.3 and $7.5 .{ }^{6}$ Fox notes that a $\mathrm{pH}$ above 6.1 reduces the formation of "formalin pigment," a derivative of hematin. ${ }^{7}$ We did not observe the formation of any pigments associated with $\mathrm{pH}$.

\section{Literature Cited}

1. Kiernan JA. Buffered ethanol fixative. J Histochem Cytochem. 2017;65(4):251.

2. Perry C, Chung JY, Ylaya K, Choi CH, Simpson A, Matsumoto KT, Smith WA, Hewitt SM. A buffered alcohol-based fixative for histomorphologic and molecular applications. J Histochem Cytochem. 2016;64(7): 425-40.

3. Chung JY, Braunschweig T, Williams R, Guerrero N, Hoffmann KM, Kwon M, Song YK, Libutti SK, Hewitt SM. Factors in tissue handling and processing that impact RNA obtained from formalin-fixed, paraffin-embedded tissue. J Histochem Cytochem. 2008;56(11):1033-42.

4. Mann G. Ueber die Behandlung der Nervenzellen fur experimentell-histologische Untersuchungen [On the treatment of nerve cells for experimental histologic investigations]. Ztschr f wiss Mikr. 1894;11:479-94.

5. Burke FV. The $\mathrm{pH}$ of formalin-a factor in fixation. Am J Pathol. 1933;9(6):915-20.

6. Lillie RD. Histopathologic technic. Philadelphia: Blakiston; 1948.

7. Fox $\mathrm{CH}$, Johnson $\mathrm{FB}$, Whiting J, Roller PP. Formaldehyde fixation. J Histo Cyto. 1985;33(8):845-53. 